\title{
Regulation of fibronectin by thyroid hormone receptors
}

\author{
Kwang-Huei Lin, Chia-yu Chen, Shen-Liang Chen, Chun-Che Yen, Ya-Hui Huang, \\ Chung-hsuan Shih, Jiann-Jong Shen ${ }^{1}$, Rong-Chi Yang ${ }^{2}$ and Chia-Siu Wang ${ }^{3}$
}

Department of Biochemistry, Chang-Gung University, Taoyuan, Taiwan, Republic of China

${ }^{1}$ School of Traditional Chinese Medicine, Chang-Gung University, Taoyuan, Taiwan, Republic of China

${ }^{2}$ Chinese Herbal Pharmacy, Chang Gung Memorial Hospital, Taoyuan, Taiwan, Republic of China

${ }^{3}$ Department of General Surgery, Chang Gung Memorial Hospital, Chiayi, Taiwan, Republic of China

(Requests for offprints should be addressed to K-H Lin; Email: khlin@mail.cgu.edu.tw)

\begin{abstract}
Thyroid hormones regulate growth, development, differentiation, and metabolic processes by interacting with and activating thyroid hormone receptors and associated pathways. We investigated the triiodothyronine $\left(\mathrm{T}_{3}\right)$ modulation of gene expression, in human hepatocellular carcinoma cell lines, via a PCR-based cDNA subtraction method. Here we present further data on one of the $T_{3}$-upregulated genes, fibronectin (FN). We demonstrate that the induction of $F N$ protein expression by $T_{3}$ in TR $\alpha 1$ and TR $\beta 1$ over-expressing cells was time and dose-dependent at the mRNA and protein levels. Blockade of protein synthesis by cycloheximide almost completely inhibited the concomitant induction of $F N$ mRNA by $T_{3}$, indicating that $\mathrm{T}_{3}$ indirectly regulates $\mathrm{FN}$. Furthermore, nuclear-run on and FN promoter assay clearly demonstrated that the presence of $\mathrm{T}_{3}$ can specifically increase the number of $F N$ transcriptional initiations. In addition, we further confirmed that the up-regulation of $\mathrm{FN}$ by $\mathrm{T}_{3}$ was mediated, at least in part, by transforming growth factor- $\beta$ (TGF- $\beta$ ), because the induction of FN was blocked in a dose-dependent manner by the addition of TGF- $\beta$ neutralizing antibody. In an effort to elucidate the signaling pathways involved in the activation of $\mathrm{FN}$ by $\mathrm{T}_{3}$, we demonstrated the involvement of the mitogen activated protein kinase/c-Jun N-terminal kinase/p38 MAPK (MAPK/JNK/p38) pathway. Although $\mathrm{T}_{3}$ induces the expression of TGF- $\beta$, neither wild-type nor dominant-negative Smad3 or Smad4 over-expression affected the activation of $\mathrm{FN}$ by $\mathrm{T}_{3}$. Thus, we demonstrate that $\mathrm{T}_{3}$ regulates $F N$ gene expression indirectly at the transcriptional level, with the participation of the MAPK/JNK/p38 pathway and the TGF- $\beta$ signaling pathway but independent of Smad3/4.
\end{abstract}

Journal of Molecular Endocrinology (2004) 33, 445-458

\section{Introduction}

The subtractive cDNA hybridization method has been used to elucidate the regulation of molecular processes during hormone treatment, cell differentiation, embryonic development, drug application and malignant transformation. This technique is a powerful approach for the identification, cloning and detailed study of relevant subsets of differentially expressed genes of interest. Recently, an improvement to this technique has been used to selectively amplify differentially expressed target cDNA fragments and simultaneously suppress the amplification of non-target DNA (Kuang et al. 1998). This new procedure overcomes previous difficulties associated with differences in mRNA abundance by incorporating a hybridization step to normalize the transcripts. We utilized the PCRbased cDNA subtraction method to examine the triiodothyronine $\left(\mathrm{T}_{3}\right)$ regulation of liver protein levels. Among these are genes including fibronectin (FN), fibrinogen, elongation factor, heat shock protein, protein disulfide isomerase, glucocorticoid receptor AF-1 specific elongation factor, and ribosomal protein L37 involved in metabolism or signal transduction. Several groups (Shirakami et al. 1986, Watzke et al. 1987) reported that thyroid hormones (THs) positively regulate plasma levels of $\mathrm{FN}$ by unknown mechanisms. In addition, Baumgartner-Parzer et al. (1997) also showed that hyperthyroidism is associated with elevated plasma levels of FN. Thus, we focused our study on the 
mechanism of how FN was regulated by THs. This initial investigation, in hepatocellular carcinoma cell lines, demonstrated that $\mathrm{FN}$ was up-regulated by $\mathrm{T}_{3}$.

THs regulate growth, development, differentiation, and metabolic processes by interacting with $\mathrm{TH}$ receptors (TRs) that, in turn, bind to specific DNA sequences in the regulatory regions of target genes (Cheng 2000). TRs are members of the steroid hormone and retinoic acid superfamily of ligand-dependent transcription factors. Two TR genes, TR $\alpha$ and $T R \beta$, have been identified and mapped to human chromosomes 17 and 3 respectively (Lazar et al. 1994). Each gene encodes at least two TR isoforms (TR $\alpha 1, \mathrm{TR} \alpha 2$, and TR $\beta 1, \mathrm{TR} \beta 2)$ that are generated as a result of alternate splicing and/or promoter choice (Wood et al. 1996). The mechanisms involved in the maintenance of liverspecific gene transcription by $\operatorname{TR} \alpha 1$ and $\operatorname{TR} \beta 1$ have not yet been fully elucidated. HepG2, a welldifferentiated hepatocellular carcinoma cell-line, has been well-characterized and has been reported to secrete all 15 known liver-specific plasma proteins. Thus, we used HepG2 to derive isogenic cell lines stably expressing high levels of wild-type $\mathrm{TR} \alpha 1$ and $\beta 1$ (HepG2-TR $\alpha 1$ and -TR $\beta 1$ cells) (Lin et al. 2000). These lines have proved to be a useful tool when investigating the target genes of THs.

FN mediates a wide variety of key interactions between cells and the extra-cellular matrix (ECM) and plays a significant role in cell adhesion, migration, growth, differentiation and the maintenance of normal cell morphology (Hynes 1985a,b, Pankov \& Yamada 2002). FN is an important glycoprotein that usually occurs as a dimer composed of two, nearly identical, $\sim 250 \mathrm{kDa}$ subunits covalently linked near their C termini by a pair of disulfide bonds (Pankov \& Yamada 2002). Although FN exists as a single gene, alternative splicing of a single pre-mRNA can generate as many as 20 variants in the human (Islami et al. 2001, Srebrow et al. 2002). These alternative splice products may contain at least three regions (ED-A, ED-B and IIICS) of the primary transcript (Borsi et al. 1990). Interestingly, it has been reported that transforming growth factor- $\beta$ (TGF- $\beta$ ) preferentially increases the accumulation of the $\mathrm{FN}$ isoforms containing the ED-A sequence in cultured normal human fibroblasts (Balza et al. 1988). FN isoforms can be classified as either soluble plasma $\mathrm{FN}$ or as the less-soluble cellular FN (Sekiguchi et al. 1986).
Plasma FN is synthesized predominantly in the liver by hepatocytes and displays a relatively simple splicing pattern. On the other hand, cellular FN consists of a much larger and more heterogeneous group of FN isoforms, resulting from cell-type and species-specific splicing patterns.

The control of FN expression by $\mathrm{T}_{3}$ and the specific isoforms of TR has not been investigated in a cellular context. We report here that $\mathrm{T}_{3}$ up-regulates $\mathrm{FN}$ expression at the transcriptional and translational level in HepG2-TR $\alpha 1$ and -TR $\beta 1$ cells. Furthermore, the effect of $\mathrm{T}_{3}$ on the level of $\mathrm{FN}$ expression requires the de novo synthesis of cellular proteins. In addition, we found that the up-regulation of $\mathrm{FN}$ by $\mathrm{T}_{3}$ is mediated, at least in part, by the TGF- $\beta$ and/or MAP kinase (MAPK) signaling pathways. The MAP family is also the TGF- $\beta$ downstream signaling mediator (Hocevar et al. 1999). Finally, we demonstrate that $\mathrm{T}_{3}$ does not utilize the TGF- $\beta$ signaling components, Smad3/4 in the control of FN expression.

\section{Materials and methods}

\section{Cell culture}

The human hepatoma cell line, HepG2, was obtained from the American Type Culture Collection (Manassas, VA, USA) and was routinely grown in Dulbecco's modified Eagle's medium (DMEM) supplemented with $10 \% \quad(\mathrm{v} / \mathrm{v})$ fetal bovine serum. TR $\alpha 1$ and $\beta 1$ over-expressing cell lines have been described previously (Lin et al. 2000). In this study, two HepG2-TR $\alpha 1-$ (\#1 and \#2) and one TR $\beta 1$-over-expressing clones were used. The serum was depleted of $\mathrm{T}_{3}(\mathrm{Td})$ as described (Samuels et al. 1979). Cells were cultured at $37^{\circ} \mathrm{C}$ in a humidified atmosphere of $95 \%$ air and $5 \% \mathrm{CO}_{2}$.

\section{Subtractive hybridization}

Total RNA from HepG2-TR $\alpha 1 \# 1$, with or without $\mathrm{T}_{3}$ treatment, was prepared using TRIzol (Life Technologies, Rockville, MD, USA). The PCR-based cDNA subtraction method was carried out according to the manufacturer's protocol (Clontech, Palo Alto, CA, USA). The subtracted cDNAs were ligated into the pGEM-T vector. Subsequently, the clones were screened for differentially expressed genes using the PGR-Select Differential Screening kit (Glontech). 


\section{Immunoblot analysis}

Cell lysates were fractionated by SDSpolyacrylamide gel electrophoresis (PAGE) on a $10 \%$ gel, and the separated proteins were transferred to a nitrocellulose membrane (Amersham, Piscataway, NJ, USA). The membrane was gently shaken for $2 \mathrm{~h}$ at room temperature in $5 \%(\mathrm{w} / \mathrm{v})$ nonfat dried milk in Tris-buffered saline (TBS), washed three times with TBS, and then incubated for $1 \mathrm{~h}$ with rabbit polyclonal antibodies to $\mathrm{FN}$ (1:1000 dilution in TBS) (Transduction, Lexington, KY, USA), or with mouse monoclonal antibody C4 to TR $\alpha 1$ (1:1000 dilution in TBS) (kindly provided by S-Y Cheng, NCI, NIH, Bethesda, MD, USA) (Bhat et al. 1995). After further washing, the membrane was incubated for $1 \mathrm{~h}$ with horseradish peroxidase conjugated to affinity-purified antibodies to either rabbit (1:1000 dilution in TBS) or mouse (1:1000 dilution in TBS) immunoglobulin (Santa Cruz Biotechnology). Immune complexes were then visualized by chemiluminescence with an ECL detection kit (Amersham). The intensities of the immunoreactive bands were quantitated by analysis with Image Gauge software (Fuji Film, Tokyo, Japan).

\section{Determination of the trans-activation activity of TRs}

$\mathrm{T}_{3}$-dependent trans-activity of TRs was assayed in the various HepG2 cell lines as described previously (Kyriakis \& Avruch 1996). Briefly, cells were transfected with a luciferase reporter plasmid $(2 \mu \mathrm{g})$ containing the Lys-TRE or FN 508 promoter $(2 \mu \mathrm{g}$, a gift from Kinichiro Oda, Science University of Tokyo, Noda, Japan) (Suzuki et al. 1998), along with a $\beta$-galactosidase plasmid $(1 \mu \mathrm{g})$ to control for transfection efficiency or TR expression vector. Transfected cells were subsequently incubated for $24 \mathrm{~h}$ in $\mathrm{Td}$ medium containing various concentrations of $\mathrm{T}_{3}$ (Sigma, St Louis, MO, USA), after which the activities of luciferase and $\beta$-galactosidase in cell lysates were measured (Flores-Morales et al. 2002). The activity of luciferase was normalized against $\beta$-galactosidase activity.

\section{Northern blot analysis}

Total RNA was extracted from cells with the use of TRIzol Reagent. Equal amounts of total RNA $(20 \mu \mathrm{g})$ were analyzed on a $1 \cdot 2 \%$ agarose- formaldehyde gel as described (Lin et al. 2002). This was then blotted onto a nitrocellulose membrane and subjected to Northern blot analysis as described (Lin et al. 2000). A full-length FN cDNA fragment was amplified, labeled with $\left[\alpha-{ }^{32} \mathrm{P}\right] \mathrm{dCTP}$ (3000 Ci/mmol; Amersham) by the PCR and used as a probe. The membrane was subsequently re-probed with a ${ }^{32} \mathrm{P}$-labeled glyceraldehyde-3phosphate dehydrogenase (GAPDH) cDNA fragment to verify equal application of RNA to each lane. In some experiments cells were treated with $\mathrm{T}_{3}$ and $10 \mu \mathrm{g} / \mathrm{ml}$ cycloheximide (Sigma) simultaneously for 12 or $24 \mathrm{~h}$, followed by total RNA isolation and Northern analysis.

\section{Nuclear run-on assay}

Sub-confluent HepG2-TRal\#1 cells were treated with or without $100 \mathrm{nM} \mathrm{T}_{3}$ for $3 \mathrm{~h}$. Cells were subsequently washed twice with ice-cold PBS, collected, and centrifuged at $500 \boldsymbol{g}$ for $5 \mathrm{~min}$ at $4{ }^{\circ} \mathrm{C}$. The pellet was gently resuspended in a buffer containing $10 \mathrm{mM}$ Tris-HCl (pH 7.4), $10 \mathrm{mM}$ $\mathrm{NaCl}, 3 \mathrm{mM} \mathrm{MgCl}$, and $0 \cdot 5 \%$ Nonidet P-40, and allowed to swell and lyse on ice for $10 \mathrm{~min}$. The lysate was recentrifuged at $500 \boldsymbol{g}$, and the resulting nuclear pellet was resuspended in $100 \mu$ labeling buffer containing $20 \mathrm{mM}$ Tris-HCl (pH 8.0), $10 \mathrm{mM} \quad \mathrm{MgCl}_{2}, \quad 140 \mathrm{mM} \quad \mathrm{KCl}, \quad 14 \mathrm{mM}$ $\beta$-mercaptoethanol, $1 \mathrm{mM} \mathrm{MnCl}_{2}$, and $20 \%$ glycerol. In vitro transcription was performed using the nuclear pellet $(100 \mu \mathrm{l})$ in labeling buffer with $1 \mathrm{mM}$ creatine kinase, $10 \mathrm{mM}$ phosphocreatine, $1 \mathrm{mM}$ CTP, ATP, GTP, and $100 \mu \mathrm{Ci}\left[\alpha{ }^{32} \mathrm{P}\right] \mathrm{UTP}$ as described previously (Liao et al. 1995). The reaction was incubated in a shaking water bath at $30{ }^{\circ} \mathrm{C}$ for $30 \mathrm{~min}$. Equal amounts $(2 \mu \mathrm{g})$ of purified, denatured full-length $\mathrm{FN}$, human $\beta$-actin, and linearized pGEM-T cDNA were vacuumtransferred onto nylon membranes using a slot blot apparatus (Amersham). The membranes were baked and pre-hybridized, as described for Northern blots. The precipitated radio-labeled transcripts $\left(\sim 10^{7} \mathrm{cpm}\right)$ were resuspended in $2 \mathrm{ml}$ hybridization buffer containing 50\% formamide, $5 \times \mathrm{SSC}, \quad 2.5 \times$ Denhardt's solution, $25 \mathrm{mM}$ sodium phosphate buffer ( $\mathrm{pH} 6 \cdot 5), 0 \cdot 1 \%$ SDS, and $250 \mu \mathrm{g} / \mathrm{ml}$ salmon sperm DNA. Hybridization of radio-labeled transcripts to the nylon membranes was carried out at $42{ }^{\circ} \mathrm{C}$ for $72 \mathrm{~h}$. The membranes were then washed with $1 \times \mathrm{SSC}$ and $0 \cdot 1 \% \mathrm{SDS}$ for 
$1 \mathrm{~h}$ at $65^{\circ} \mathrm{C}$ before auto-radiography for $24 \mathrm{~h}$ at $-80^{\circ} \mathrm{C}$.

\section{Quantitative reverse transcription-polymerase chain reaction (Q-RT-PCR)}

To determine the expression of TGF- $\beta$, Q-RTPGR was carried out. Total RNA was extracted from cells using TRIzol as described above. Subsequently, the first strand of cDNA was synthesized using the Superscript III kit for RT-PCR (Life Technologies). Real time Q-RTPGR was performed in a $25 \mu \mathrm{l}$ reaction mixture containing $50 \mathrm{nM}$ forward and reverse primers, $1 \times$ SYBR Green reaction mix (Applied Biosystems, Foster City, CA, USA), and various amounts of template. Fluorescence emitted by SYBR Green was detected on line by the ABI PRISM 7000 sequence detection system (Applied Biosystems). All PGRs were carried out in duplicate on the same 96-well plate. For quantification of gene expression changes, the $\Delta \mathrm{Ct}$ method was used to calculate relative-fold changes normalized against the ribosomal binding protein (RiboL35A) gene as described in User Bulletin number 2 (Applied Biosystems). The Ct is defined as the cycle at which fluorescence is determined to be statistically significant above background.

\section{TGF- $\beta$ protein assay}

To determine the effect of $\mathrm{T}_{3}$ on the expression of TGF- $\beta$ protein, TGF- $\beta 1$ Emax ImmunoAssay System (Promega Corporation, Madison, WI, USA) was used. Briefly, HepG2-TRa1\#1 cells were treated with or without 10 to $100 \mathrm{nM} \mathrm{T}_{3}$ for various times. The supernatant was collected for TGF- $\beta$ determination according to the manufacturer's instructions.

\section{Determination of the effect of exogenous Smad on FN expression}

To determine the exogenous effect of Smad on the expression of $\mathrm{FN}$, we transfected HepG2-TR $\alpha 1 \# 1$ cells $\left(1 \sim 2 \times 10^{5}\right.$ per $60-\mathrm{mm}$ dish $)$ with wild-type or dominant-negative Smad plasmid using Lipofectamine (Gibco BRL). Twenty-four hours after transfection, the cells were lysed and Western blot analysis performed. Smad plamids were a gift from Dr P T Dijke (Ludwig Institute, Uppsala, Sweden).

\section{Results}

\section{Expression and trans-activation activity of TRa1 and TRß1 in HepG2 cell lines}

We used a PGR-based cDNA subtraction method to identify the induction of genes by $\mathrm{T}_{3}$ in HepG2 cells. FN was selected because the control mechanism of its expression by $\mathrm{T}_{3}$ and $\mathrm{TR}$ has not been studied. To further investigate the molecular regulation by $\mathrm{T}_{3}$ of the $F \mathcal{N}$ gene, we used isogenic HepG2 cell lines that stably express wild-type TR $\alpha 1$ (HepG2-TR $\alpha 1$ clones \#1, \#2) and TR $\beta 1$ (HepG2-TR $\beta 1$ ). As a control, HepG2 cells were transfected with the empty vector, yielding a cell line that expresses the Neo protein (HepG2-Neo cells). Prominent immunoreactive bands, corresponding to TR $\alpha 1$ or $T R \beta 1$ were detected in HepG2-TR $\alpha 1 \# 1$, \#2, and HepG2-TR $\beta 1$ using the monoclonal antibody C4 (Fig. 1). This antibody recognizes an epitope at the $\mathrm{COOH}$-terminus of TR $\alpha 1$ and TR $\beta 1$ (Bhat et al. 1995). Quantitation of the immunoreactive bands revealed that the abundance of TR $\alpha 1$ protein in HepG2-TR $\alpha 1$ cells was four- to sevenfold that in HepG2-Neo cells. Endogenous levels of TR in HepG2-Neo cells were only faintly observed after longer exposure times.

A Lys-luciferase reporter construct (containing the thyroid hormone response element (TRE) of the chicken lysozyme gene, a 6 nt inverted repeat), was used to compare the transcriptional activity of TR $\alpha 1$ in HepG2-TR $\alpha 1 \# 1$ and \#2 and of TR $\beta 1$ in HepG2-TR $\beta 1$ with that of the HepG2-Neo cells (Fig. 1B). HepG2-TR $\alpha 1 \# 1$ and HepG2-TR $\beta 1$ cells exhibited higher trans-activity (five- to sevenfold), which increased in a $\mathrm{T}_{3}$-dependent manner. TR 1 1\#2 displayed moderate trans-activation of the reporter construct (three-to fourfold), while the control HepG2-Neo cells exhibited a low level of trans-activity (Fig. 1B). These results indicate that the isogenic cell lines over-express TR $\alpha 1$ or TR $\beta 1$ and the level of expression correlates well with their functional capacity to trans-activate the expression of downstream genes.

\section{Effects of $T_{3}$ on the abundance of $F N$ protein and mRNA in HepG2-TR $\alpha 1$ and TRß1 cell lines}

Next, we were interested in the effect of the TRs on the level of FN protein expression when the HepG2 isogenic cell lines were incubated in media containing various levels of $\mathrm{T}_{3}$ across different time 


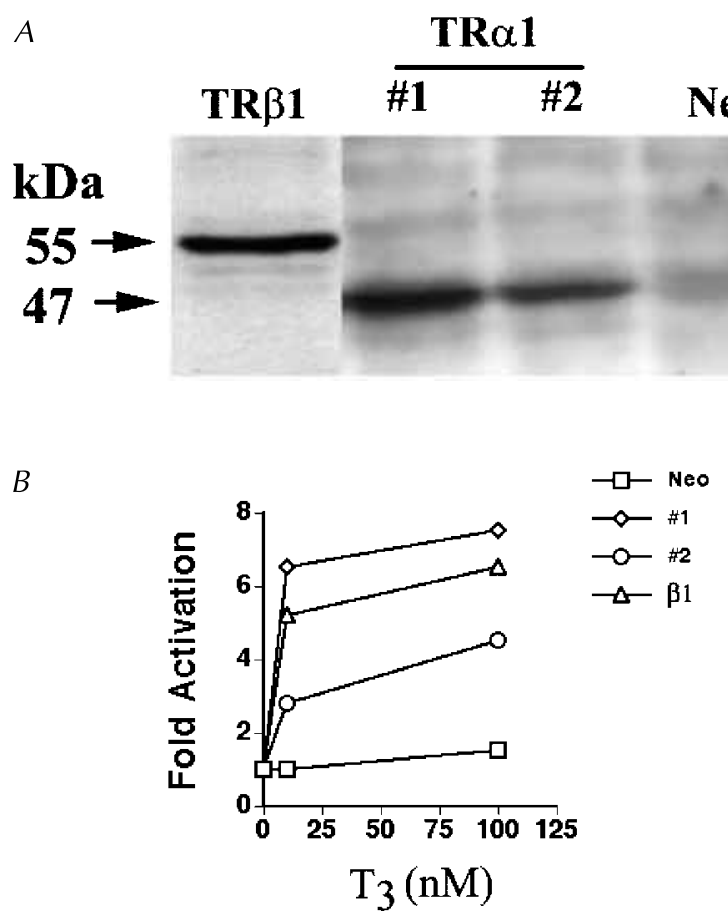

Figure 1 Expression and trans-activity of TR $\alpha 1$ and TR $\beta 1$ in HepG2 cell lines. (A) Immunoblot analysis of TR $\alpha 1$ and TR $\beta 1$ expression in isogenic HepG2 cell lines. Lysates (100 $\mu \mathrm{g}$ protein) from HepG2-TR $\alpha 1 \# 1$, \#2, TR $\beta 1$ ( $\beta 1)$ and HepG2-Neo (Neo) cells were subjected to immunoblot analysis with monoclonal antibody $\mathrm{C} 4$ as described in Materials and Methods. The positions of the $47 \mathrm{kDa}$ TR $\alpha 1$ protein or $55 \mathrm{kDa}$ TR $\beta 1$ protein are indicated. Tubulin was used as an internal control (data not shown). (B) $T_{3}$-dependent trans-activity of TRs in the various HepG2 cell lines. Cells were transfected with a luciferase reporter plasmid containing the Lys-TRE, as well as with a $\beta$-galactosidase plasmid to control for transfection efficiency. They were subsequently incubated for $24 \mathrm{~h}$ in $\mathrm{T}_{3}$-depleted $(\mathrm{Td})$ medium containing the indicated concentrations of $T_{3}$, after which the activities of luciferase and $\beta$-galactosidase in cell lysates were measured. The activity of luciferase was normalized on the basis of the activity of $\beta$-galactosidase. Data are from three independent experiments, each performed in duplicate. The ordinate indicates 'Fold Activation' and non-induced $=1$.

points (Fig. 2). $\mathrm{T}_{3}$ significantly increased the abundance of FN in the HepG2-TR $\alpha 1 \# 1, \# 2$ and -TR $\beta 1$ stable cell lines as compared with the HepG2-Neo control cell line. FN levels increased approximately $1 \cdot 5$ - to $2 \cdot 5$-fold after incubation of HepG2-TR $\alpha 1 \# 1$, \#2, and TR $\beta 1$ cells with $10 \mathrm{nM}$ $\mathrm{T}_{3}$ for $24 \mathrm{~h}$. In addition, $100 \mathrm{nM} \mathrm{T}_{3}$ for $24 \mathrm{~h}$ gave a slightly greater and more significant induction
(2.2- to $2 \cdot 8$-fold) of $\mathrm{FN}$ protein. Moreover, after $48 \mathrm{~h}$ incubation in $100 \mathrm{nM} \mathrm{T}, \mathrm{FN}$ activation was further elevated $(\sim 2 \cdot 5-$ to $\sim 4 \cdot 2$-fold $)$. These results indicate that the effect of $\mathrm{T}_{3}$ on the level of FN in TR $\alpha 1$ and $\beta 1$ over-expressing cells was timeand dose-dependent. In addition, immunoblot analysis revealed that exposure of control HepG2Neo cells, expressing endogenous levels of TR proteins, to $100 \mathrm{nM} \mathrm{T}_{3}$, resulted in little effect on the expression of FN protein (Fig. 2). Thus, the extent of $\mathrm{FN}$ protein induction by $100 \mathrm{nM} \mathrm{T}_{3}$ correlated with the level of TR protein expression.

Northern blot analysis was utilized to examine the response of $F \mathcal{N}$ mRNA expression to the exogenous addition of $\mathrm{T}_{3}$. In all three cell lines investigated, a $9 \mathrm{~kb} F \mathcal{N}$ transcript was detected (Fig. 3A). Exposure to $100 \mathrm{nM} \mathrm{T} \mathrm{T}_{3}$ for $24 \mathrm{~h}$ resulted in a significant induction in the expression of $F N$ mRNA in HepG2TR $\alpha 1 \# 1, \# 2$ and TR $\beta 1$ cells, with increases of 2.8-, $2 \cdot 6$ - and $2 \cdot 5$-fold respectively. This suggests that the augmented expression of $F \mathcal{N}$ mRNA in response to $\mathrm{T}_{3}$ corresponds to the amount of TR in the individual line. The highest levels of $\mathrm{T}_{3}(100 \mathrm{nM})$ used in this experiment did not significantly increase the level of FN expression above that already displayed in the $10 \mathrm{nM} \mathrm{T}_{3}$ experiment (Fig. 3B).These results indicate that $F \mathcal{N}$ gene expression may be very sensitive to the presence of small amounts of $T_{3}$ in the medium. Applying $10 \mathrm{nM} \mathrm{T}_{3}$ for $24 \mathrm{~h}$ or $48 \mathrm{~h}$, to the HepG2-TR $\beta 1$ cell line, increased FN levels $1 \cdot 5$ - and $2 \cdot 0$-fold respectively. However, when the cells were exposed to $100 \mathrm{nM} \mathrm{T}_{3}$ for $24 \mathrm{~h}$ or $48 \mathrm{~h} F \mathcal{N}$ mRNA expression increased $2 \cdot 5$ - and $3 \cdot 5$-fold respectively. This indicates that the action of $\mathrm{T}_{3}$ in TR $\alpha 1$ as compared with the TR $\beta 1$ stable cell line was slightly different. $F \mathcal{N}$ mRNA levels were less sensitive to the presence of $\mathrm{T}_{3}$ in the TR $\beta 1$ compared with the TR $\alpha 1$ stable cell line. Furthermore, $\mathrm{T}_{3}$ had little effect on the abundance of $F \mathcal{N}$ mRNA in HepG2Neo cells (Fig. 3). Thus, the effect of $\mathrm{T}_{3}$ on the expression of FN protein appears to be mediated, at least in part, at the mRNA level.

\section{Effects of $\mathrm{T}_{3}$ and cycloheximide ( $\left.\mathrm{CHX}\right)$ on the abundance of FN mRNA}

In an effort to further delineate the regulatory action of $\mathrm{T}_{3}$ on the expression of $F \mathcal{N}$ mRNA, a protein synthesis inhibitor, CHX, was employed. Induction of $F \mathcal{N}$ mRNA expression by $\mathrm{T}_{3}$, in the presence or absence of CHX, was observed for 
A HepG2-TR $\alpha 1 \# 1$

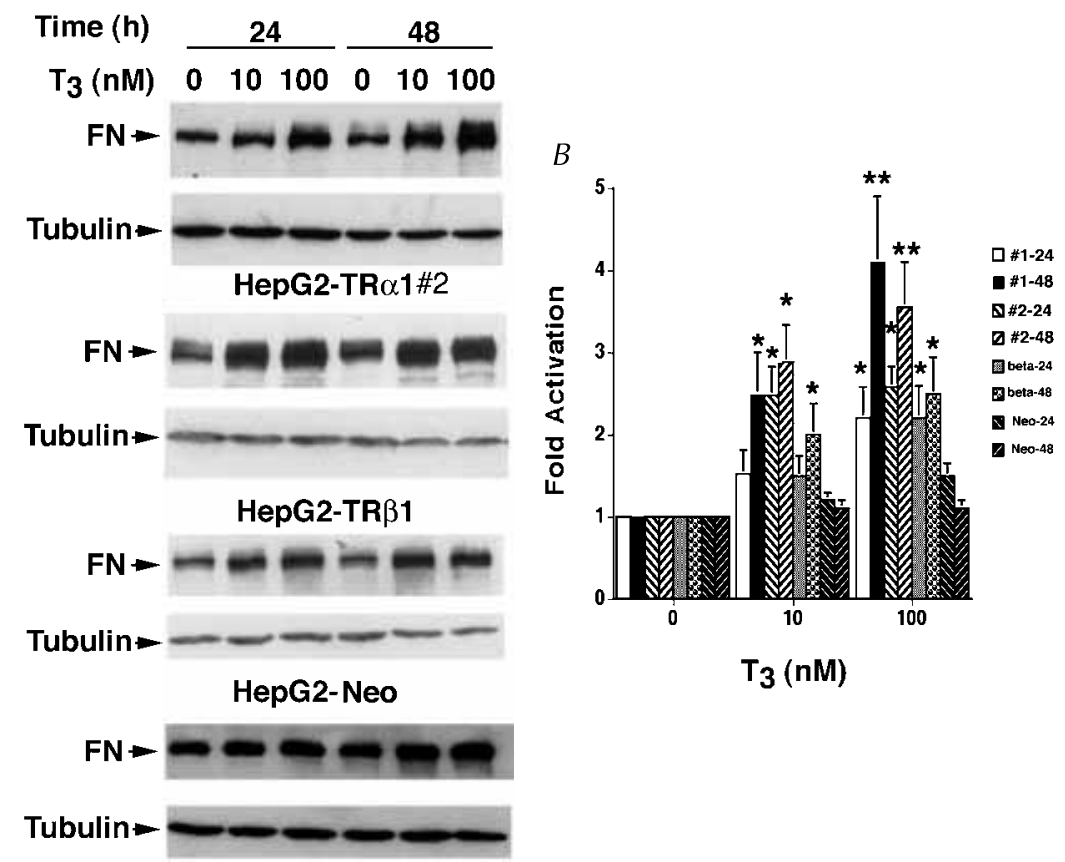

Figure 2 The effect of $T_{3}$ on $F N$ protein expression in HepG2 cell lines. (A) HepG2-TR $\alpha 1 \# 1$ and \#2, -TR $\beta 1$ (beta) and -Neo cells were incubated with medium in the absence or presence of $T_{3}$ for 24 or $48 \mathrm{~h}$. Subsequently, cell lysates $(100 \mu \mathrm{g}$ protein) were subjected to immunoblot analysis with polyclonal antibodies to FN. The position of the $250 \mathrm{kDa} F N$ protein is indicated. Tubulin was used as an internal control. (B) The intensities of bands in $(A)$ were quantified and the extent of $T_{3}$-induced activation of $F N$ expression was determined at each time point. In the key, \#1-24 and \#1-48 represents the data for HepG2-TR $\alpha 1 \# 1$ at 24 and $48 \mathrm{~h}$ incubation respectively. The other three cell lines are similarly represented in the key. Data are means \pm S.E of values from three independent experiments. Values are shown as fold induction of the Td-control. ${ }^{*} P<0.05$, ${ }^{\star *} P<0.01, \mathrm{~T}_{3}$ compared with Td-treated (Student's $t$-test).

both time periods in HepG2-TR $\alpha$ l\#1 cells. The transcriptional response of $F \mathcal{N}$ mRNA to $\mathrm{T}_{3}$ over 12- and 24-h periods was greatly reduced in the presence of CHX (Fig. 4). Similar results were observed in the other two TR over-expressing cell lines (data not shown). These data indicate that blocking protein synthesis almost completely inhibits the induction of $F \mathcal{N}$ transcription by $\mathrm{T}_{3}$. It follows from this result that de novo protein synthesis may be required for this activation to occur.

\section{$\mathrm{T}_{3}$ induces the expression of $\mathrm{FN}$ at the transcriptional level}

To further confirm that regulation of $F \mathcal{N}$ expression by $\mathrm{T}_{3}$ occurred at the transcriptional level we performed nuclear run-on experiments. $\mathrm{T}_{3}$ induced an approximate $2 \cdot 5$-fold increase in $F \mathcal{N}$ mRNA transcription (Fig. 5), as observed in the Western and Northern blots. The expression levels of $\beta$-actin were used as an internal control, and pGEM-T vector as a negative control. The data clearly demonstrate that $\mathrm{T}_{3}$ can specifically increase the number of $F \mathcal{N}$ transcripts in HepG2-TR $\alpha 1 \# 1$ cells.

To further support this conclusion, we carried out reporter assays. We used the $F \mathcal{N} 5$ '-flanking region encompassing nucleotides $-508 /+18$ (Suzuki et al. 1998) and then placed it upstream of the luciferase reporter gene in pGL2. Using this reporter, we determined the effect of transactivation of $F \mathcal{N}$ by $\mathrm{T}_{3}$. As shown in Fig. 6, at 


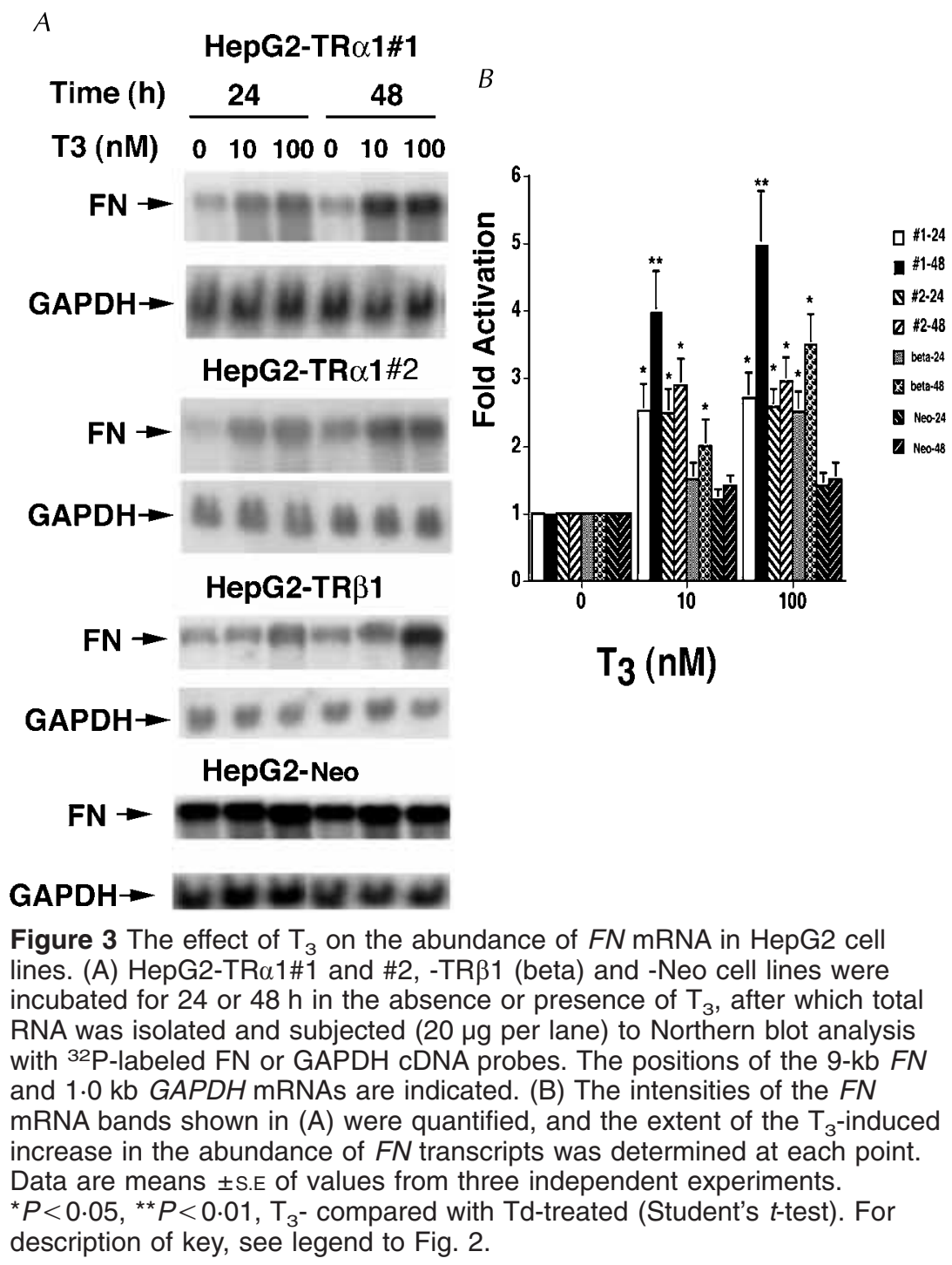

$100 \mathrm{nM} \mathrm{T}$, FN promoter had the highest activity (approximately $2 \cdot 2$-fold activation). Therefore, the $F \mathcal{N}$ promoter was sensitive to $\mathrm{T}_{3}$ treatment.

\section{Effects of $T_{3}$, TGF- $\beta$ and MAP kinase on the abundance of FN protein}

In an effort to elucidate the signaling pathways involved in the activation of $\mathrm{FN}$ by $\mathrm{T}_{3}$, we demonstrated the involvement of the TGF- $\beta$ and/or MAPK/c-Jun N-terminal kinase/p38 MAP kinase (MAPK/JNK/p38) pathway. Our data indicate that treatment of cells with $\mathrm{T}_{3}$ for various times induces TGF- $\beta$ expression from $1 \cdot 7$ - to 3.3-fold at the mRNA level (Table 1). Similarly, treatment of cells with 10 to $100 \mathrm{nM} \mathrm{T}_{3}$ for various times induces TGF- $\beta$ expression from $1 \cdot 5-$ to $3 \cdot 8$-fold at the protein level (Table 2). This is consistent with the report by Miller et al. (2001). We further confirmed that the induction of $\mathrm{FN}$ by $\mathrm{T}_{3}$ was mediated by TGF- $\beta$ (Fig. 7). Figure 7 indicates that the induction of $\mathrm{FN}$ by $\mathrm{T}_{3}$ was blocked in a dose-dependent manner by the addition of TGF- $\beta$ neutralizing antibody but not by the control antibody. Furthermore, it has been demonstrated that TGF- $\beta$ signaling is mediated by members of the MAPK family in the induction of $\mathrm{FN}$ expression (Hocevar et al. 1999). To determine if the role of $\mathrm{T}_{3}$ or recombinant TGF- $\beta$ on the induction of FN in HepG2-TR $\alpha 1 \# 1$ cell lines is 
A
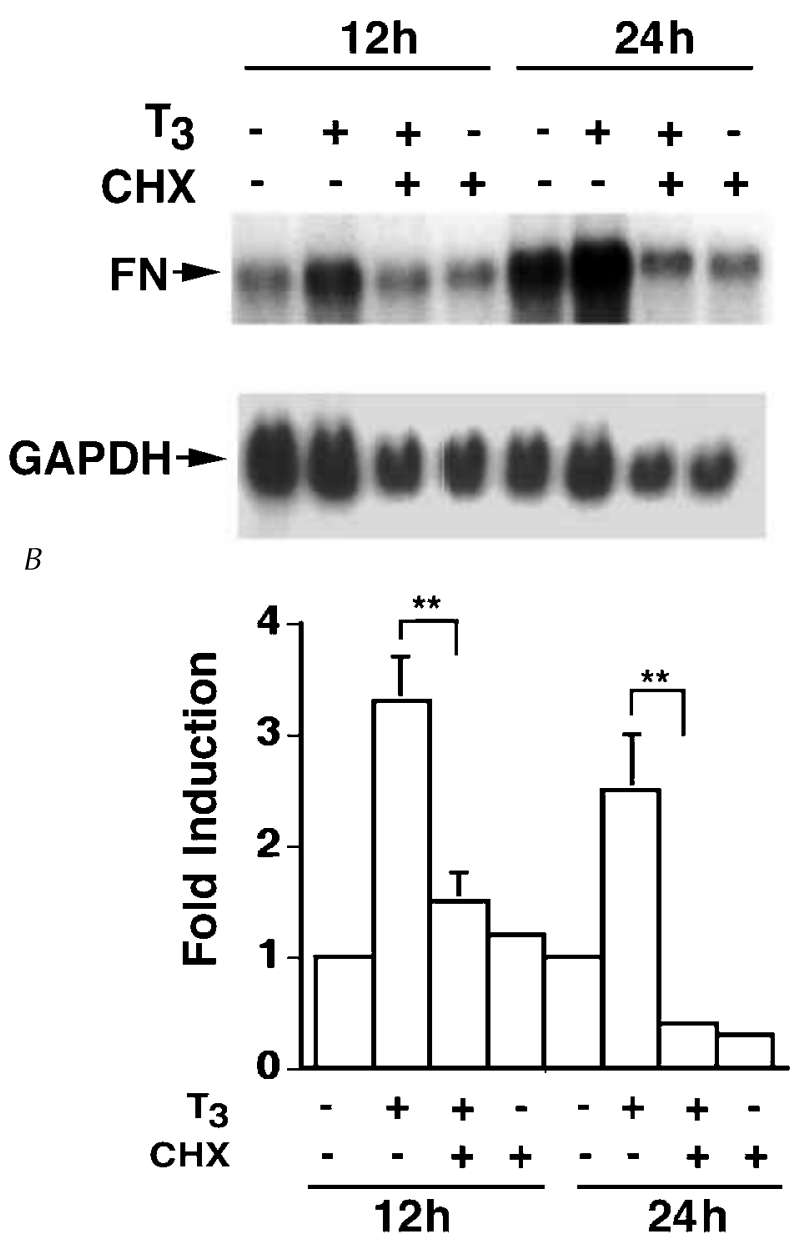

Figure 4 The effect of cycloheximide (CHX) on the response of $\mathrm{FN}$ to $\mathrm{T}_{3}$-activation. (A) HepG2-TR $\alpha 1$ \#1 cells were treated as described in Fig. 3 with or without $10 \mu \mathrm{g} / \mathrm{ml} \mathrm{CHX}$. After $\mathrm{T}_{3}$-activation for 12 or $24 \mathrm{~h}$, total RNA was isolated and subjected ( $20 \mu \mathrm{g}$ per lane) to Northern blot analysis. (B) The intensities of the $F N$ and GAPDH mRNA bands on blots were quantified, and the increase in abundance of $F N$ transcripts was determined at each time point. The data from three independent experiments are displayed as a fold induction compared with those exposed to the control (Td) media. ${ }^{* \star} P<0.01$, no $\mathrm{CHX}$ compared with CHX-treated (Student's $t$-test).

mediated by MAPKs, we investigated the effect of several MAPK inhibitors. PD98059 is a selective inhibitor of MAPK kinase (MEK) $1 / 2$ that blocks extracellular signal-regulated kinase (ERK) activation, whereas SB203580 inhibits both JNK and p38 MAPK, and SB202190 is a specific inhibitor of p38 MAPK. These inhibitors were applied

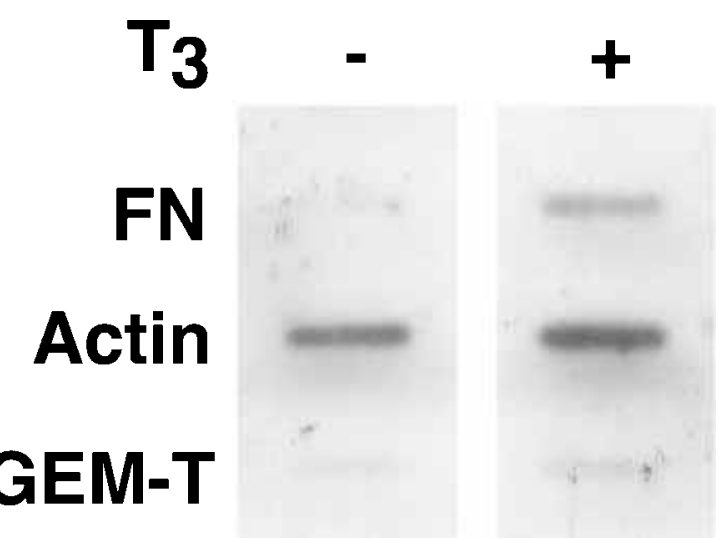

Figure 5 The effect of $\mathrm{T}_{3}$ on $F N$ gene transcription rate, measured in a nuclear run-on assay using HepG2-TR $\alpha 1$ \#1 cells. Nuclei were isolated after cells were treated with or without $100 \mathrm{nM} \mathrm{T}_{3}$ for $3 \mathrm{~h}$. These were subjected to in vitro transcription using the nuclear pellet as the template and hybridizing this product against denaturized-linear plasmids that contain the CDNAs indicated at the left of the Figure. Actin, and pGEM-T were used as internal controls.

individually to HepG2-TRal\#l cells $3 \mathrm{~h}$ before the addition of $100 \mathrm{nM} \mathrm{T}$. After incubation for an additional $24 \mathrm{~h}$, the induction of $\mathrm{FN}$ protein in the absence of inhibitors was $\sim$ threefold, as seen previously (Fig. 2). FN was also stimulated $\sim$ threefold by TGF- $\beta$. However, the activation of $\mathrm{FN}$ by $\mathrm{T}_{3}$ or TGF- $\beta$ was completely abolished after the addition of $15 \mu \mathrm{M}$ SB203580 or SB202190 (Fig. 8). In contrast, this inhibition was not observed with the application of the inhibitor PD98059 $(10 \mu \mathrm{M})$. These data indicate that activation of $\mathrm{FN}$ by $\mathrm{T}_{3}$ or TGF- $\beta$ is mediated, at least in part, by the JNK or p38, but not the MEK/ERK pathway.

\section{Stimulation of $\mathrm{FN}$ by $\mathrm{T}_{3}$ is not mediated by the Smad 3/4-dependent pathway}

The MAPK family has been implicated in the events downstream of TGF- $\beta$ signaling (Marais \& Marshall 1996). TGF- $\beta$ signaling is mediated by the phosphorylation and activation of either Smad2 or Smad3, which allows the formation of a heterodimeric complex with Smad4. This complex subsequently trans locates into the nucleus, where it acts on the promoters of target genes (Itoh et al. 2000). Therefore, we investigated the possible role of $\mathrm{Smad} 3 / 4$ in the $7 \mathcal{N K} / p 38$-mediated activation of $\mathrm{FN}$ protein by $\mathrm{T}_{3}$. Both wild-type and dominantnegative forms of $\mathrm{Smad} 3$ and $\mathrm{Smad} 4$ were 


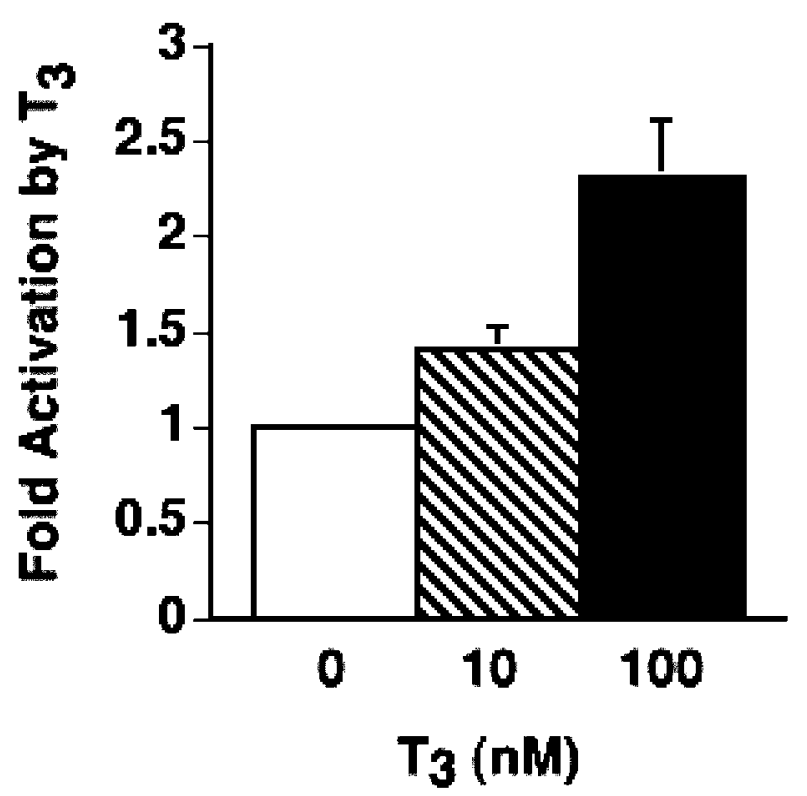

Figure $6 \mathrm{~T}_{3}$-dependent trans-activity of TR $\beta 1$ in $F N$ promoter. Cells were transfected with a luciferase reporter plasmid containing the $F N 5^{\prime}$-flanking region encompassing nucleotides -508/+18 (Suzuki et al. 1998), TR $\beta 1$, as well as with a $\beta$-galactosidase plasmid to control for transfection efficiency. They were subsequently incubated for $24 \mathrm{~h}$ in $\mathrm{T}_{3}$-depleted $(\mathrm{Td})$ medium containing the indicated concentrations of $T_{3}$, after which the activities of luciferase and $\beta$-galactosidase in cell lysates were measured. The activity of luciferase was normalized on the basis of the activity of $\beta$-galactosidase. Data are from three independent experiments, each performed in duplicate. The ordinate indicates 'Fold Activation' and non-induced $=1$.

Table 1 Induction of TGF- $\beta$ mRNA by $100 \mathrm{nM} \mathrm{T}_{3}$ in HepG2-TR $\alpha \# 1$ cells by Q-RT-PCR. Data are displayed as fold induction by $T_{3}$ (mean \pm S.E. of three independent experiments)

\begin{tabular}{lll} 
Hours after $\mathrm{T}_{3}$-treatment & \\
\hline 6 & $\frac{12}{1.8 \pm 0.2}$ & 38 \\
& & $3.3 \pm 0.5$ \\
\hline
\end{tabular}

transiently over-expressed in HepG2-TR $\alpha 1 \# 1$ cells to observe their effect on $\mathrm{T}_{3}$-mediated $\mathrm{FN}$ activation. Interestingly, neither the overexpression of wild-type nor dominant-negative Smad3 or Smad4 affected the activation of FN by $\mathrm{T}_{3}$ (Fig. 9). This indicates that these components of the TGF- $\beta$ signaling pathway are not involved in the $\mathrm{T}_{3}$-mediated transcriptional activation of $\mathrm{FN}$.

\section{Discussion}

We reported here the isolation of $\mathrm{T}_{3}$-responsive genes using a PCR-based cDNA subtraction method in HepG2 cell lines over-expressing TR $\alpha 1$ protein. One gene $(F \mathcal{N}$, the extra-cellular matrix component) that was significantly induced by $\mathrm{T}_{3}$ was targeted because several groups (Shirakami et al. 1986, Watzke et al. 1987, Baumgartner-Parzer et al. 1997) have reported a significant positive correlation between plasma concentrations of FN and total THs. However, no detail of the regulation mechanism has been reported. HepG2, a welldifferentiated hepatocellular carcinoma cell-line, secretes all 15 plasma proteins (Chang et al. 1983) and preserves many liver-specific functions. Thus, the HepG2 cell line serves as a suitable model system to study the cell type-specific and TR isoform-specific regulation of $\mathrm{T}_{3}$-target genes in the liver (Lin et al. 1997). The liver is the major target organ of THs (Cheng 2000) and is the main site of FN secretion (Pankov \& Yamada 2002). However, the mechanisms of how TRs selectively maintain liver-specific gene transcription have not yet been elucidated. Furthermore, the use of cells overexpressing TRs enabled us to investigate the regulation of plasma protein levels in response to variations in the levels and isoforms of the TR receptors. Therefore, in this study we investigated the molecular regulation of $\mathrm{FN}$ by $\mathrm{T}_{3}$ in isogenic HepG2 cell lines.

Table 2 Induction of TGF- $\beta$ protein by 10 or 100 nM T 3 in HepG2-TR $\alpha \# 1$ cells. Data are displayed as fold induction by $\mathrm{T}_{3}$ (mean \pm S.E. of three independent experiments)

\begin{tabular}{|c|c|c|c|c|c|c|}
\hline & \multicolumn{6}{|c|}{ Hours after $T_{3}$-treatment } \\
\hline & \multicolumn{2}{|l|}{6} & \multicolumn{2}{|l|}{12} & \multicolumn{2}{|l|}{48} \\
\hline & $10 \mathrm{nM} \mathrm{T}_{3}$ & $100 \mathrm{nM} \mathrm{T}_{3}$ & $10 \mathrm{nM} \mathrm{T}_{3}$ & $100 \mathrm{nM} \mathrm{T}_{3}$ & $10 \mathrm{nM} \mathrm{T}_{3}$ & $100 \mathrm{nM} \mathrm{T}_{3}$ \\
\hline TGF- $\beta$ protein & $1 \cdot 5 \pm 0 \cdot 3$ & $1 \cdot 8 \pm 0 \cdot 2$ & $1 \cdot 6 \pm 0 \cdot 1$ & $2 \cdot 0 \pm 0.2$ & $2 \cdot 6 \pm 0.4$ & $3 \cdot 8 \pm 0.5$ \\
\hline
\end{tabular}




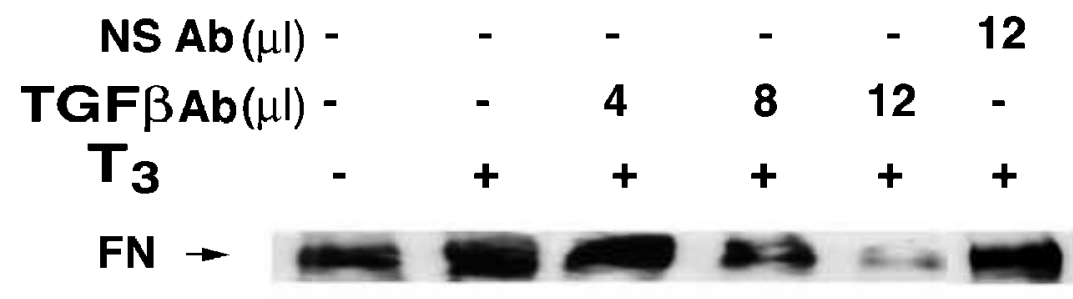

\section{Tubulin $\rightarrow$}

$B$

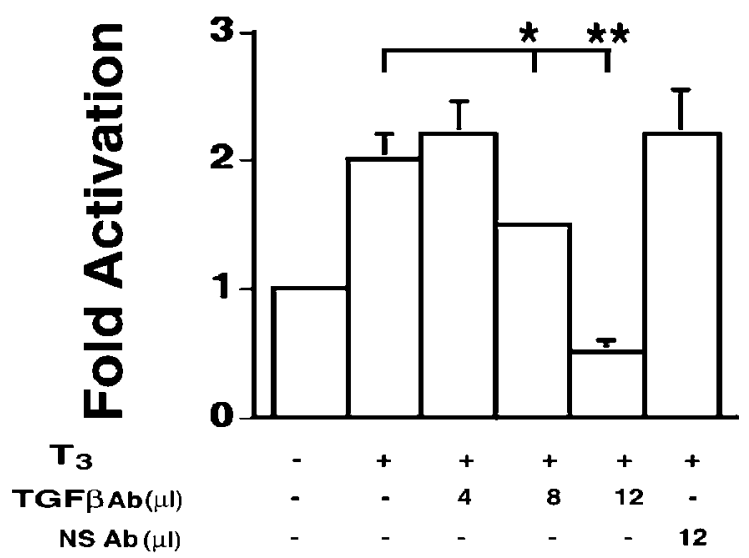

Figure $7 \mathrm{~T}_{3}$-induced FN expression was blocked by the TGF- $\beta$ antibody. (A) FN was induced by $100 \mathrm{nM} \mathrm{T}_{3}$ in HepG2 TRa\#1 cells for $24 \mathrm{~h}$. Some other tubes were incubated simultaneously with $T_{3}$ and increasing volumes $(4 \sim 12 \mu \mathrm{l})$ of the TGF- $\beta$ or non-specific (NS) control antibody (Ab).

Subsequently, cell lysates (100 $\mu \mathrm{g}$ protein) were subjected to immunoblot analysis with polyclonal antibodies to FN. Tubulin was used as an internal control. (B) The intensities of bands in (A) were quantified and the extent of $\mathrm{T}_{3}$-induced activation of $\mathrm{FN}$ expression was determined in each lane. Data are means \pm S.E of values from three independent experiments. Values are shown as fold induction of the Td-control. ${ }^{\star} P<0.05$, ${ }^{\star *} P<0.01, T_{3}$ compared with TGF- $\beta$ Ab-treated (Student's $t$-test).

Although this study investigated the induction of $\mathrm{FN}$ by $\mathrm{T}_{3}$ in human hepatoma cell lines, similar results have also been observed in animal and primary cell culture models. Murata et al. (1990) showed that $F \mathcal{N}$ mRNA was decreased by half in thyroidectomized rats, while administration of physiological doses of thyroxine or $\mathrm{T}_{3}$ for $5-6$ days restored $F \mathcal{N}$ mRNA to control levels. Moreover, administration of pharmacological doses of thyroid hormones induced a further increase in the abundance of $F \mathcal{N}$ mRNA. Subsequently, Lee et al. (1992) demonstrated that TH promotes $F \mathcal{N}$ gene expression in primary cultured rat hepatocytes, yet inhibits FN synthesis in cultured human skin fibroblasts. Furthermore, in hepatocytes, these authors demonstrated that $\mathrm{TH}$ directly enhanced $F \mathcal{N}$ gene expression without requiring de novo protein synthesis. In contrast, we demonstrate the need for de novo protein synthesis for the induction of $\mathrm{FN}$ by $\mathrm{T}_{3}$ in HepG2 cell lines. The discrepancy between these results may be due, in part, to the previous authors using dot blot hybridization instead of the more sensitive Northern blot, to determine the effect of CHX on induction of $F \mathcal{N}$ mRNA by $\mathrm{T}_{3}$ (see Fig. 5 of their paper) (Lee et al. 1992). This inconsistency cannot be commented on 


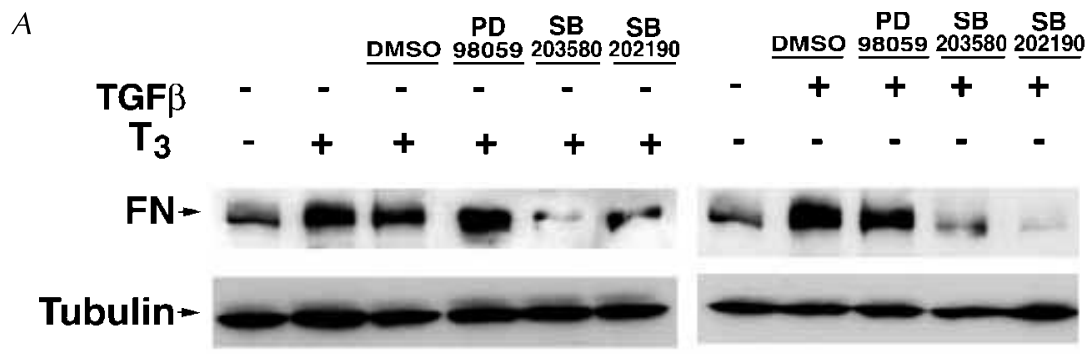

B

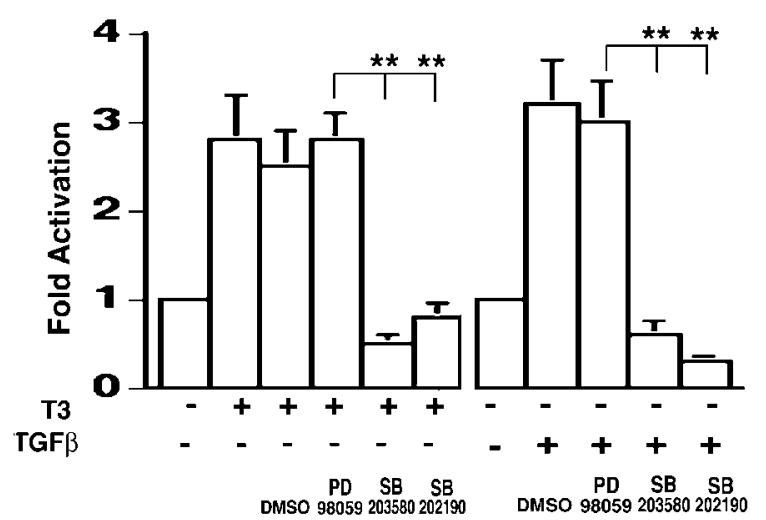

Figure $8 \mathrm{~T}_{3}$ - and TGF- $\beta$-induced FN expression was blocked by the JNK/p38 inhibitors, SB203580 and SB202190. (A) HepG2 TRa\#1 cells were treated with the MAPK inhibitor PD98059 $(10 \mu \mathrm{M})$ and other pathway inhibitors SB203580 $(15 \mu \mathrm{M})$ and SB202190 $(15 \mu \mathrm{M}) 3 \mathrm{~h}$ before the addition of $100 \mathrm{nM} \mathrm{T}_{3}$, prior to immunoblotting. Tubulin was used as an internal control. (B) The intensities of the immunoblot bands were quantified to determine the changes in FN abundance at each time point. The data are displayed as fold activation compared with those in $\mathrm{Td}$ media and are taken from three independent experiments. ${ }^{* *} P<0.01, \mathrm{~T}_{3} / \mathrm{SB} 203580$ - or $\mathrm{T}_{3} / \mathrm{SB} 202190$-treated compared with $\mathrm{T}_{3}$ - or $\mathrm{T}_{3}$ /DMSO-treated; TGF- $\beta /$ SB203580- or TGF- $\beta /$ SB202190-treated compared with TGF- $\beta /$ DMSO-treated (Student's $t$-test).

further as the previous authors did not present their dot blot data, although it would be very difficult to determine the effect of CHX on FN expression as their data indicate that $\mathrm{T}_{3}$ did not induce $F \mathcal{N}$ mRNA expression (see Fig. 4 of their paper). Our data clearly show that $F \mathcal{N}$ mRNA induction by $\mathrm{T}_{3}$ is in-directed, de novo protein synthesis required.

Additionally, studies in humans and animal models further support our findings. Watzke et al. (1987) studied the plasma concentration of $\mathrm{FN}$ in 13 untreated thyroid carcinoma patients after total thyroidectomy. FN levels were found to be significantly decreased compared with those of healthy volunteers. Following oral administration of L-thyroxine for 6 weeks, the same patients showed significantly increased levels of FN compared with untreated patients. In support of this data, fibronectin expression in hypothyroid animals is reduced to about $40 \%$ in the midbrain compared with untreated animals (Calloni et al. 2001). Furthermore, in vivo animal studies demonstrated that $\mathrm{TH}$ s promote the expression of the $F \mathcal{N}$ gene in the rat liver (Lee et al. 1992).

In this report we examined the potential role played by TGF- $\beta$ in the enhanced expression of FN by $\mathrm{T}_{3}$. This pathway was investigated, as there is evidence of a close relationship between $\mathrm{T}_{3}$ and TGF- $\beta$. A previous report (Miller et al. 2001) and ours have demonstrated that treatment with $\mathrm{T}_{3}$ for $12 \mathrm{~h}$ or more induces TGF- $\beta$ expression. Furthermore, an increased TGF- $\beta$ plasma concentration was reported to be associated with high plasma $T_{3}$ levels in elderly patients with non-thyroidal illnesses (Corica et al. 1998). In addition, TGF- $\beta$ signaling 
A
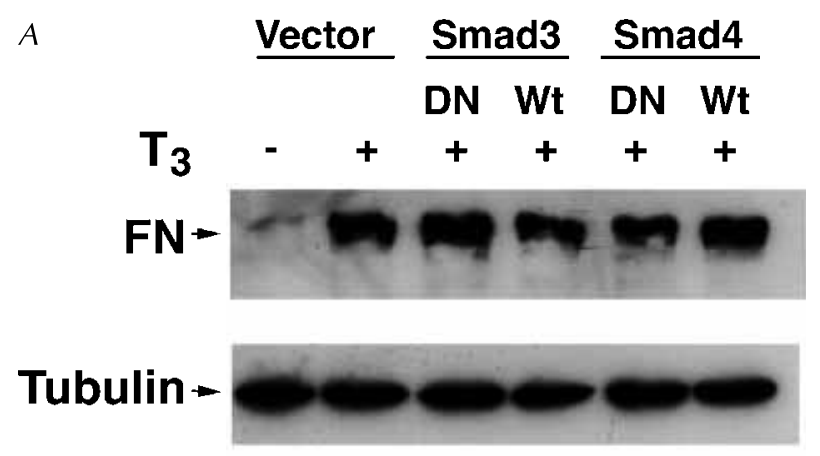

$B$

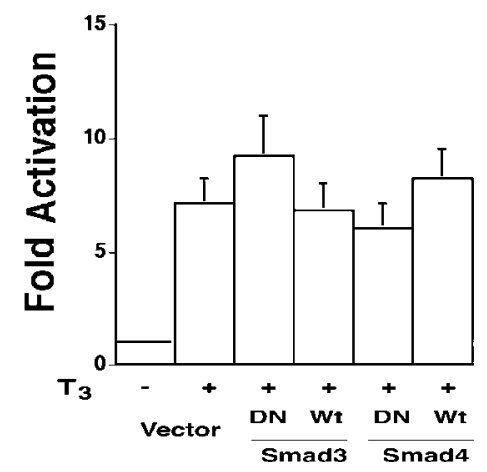

Figure $9 \mathrm{Smad} 3 / 4$ were not involved in $\mathrm{T}_{3}$-induced $\mathrm{FN}$ expression. (A) To determine the effect of Smad proteins, dominant-negative (DN) and wild type (Wt) Smad3 or Smad4 plasmids were transfected into HepG2 TRa\#1 in the presence of $T_{3}$. Tubulin was used as an internal control. (B) The intensities of the immunoblot bands were quantified and represented in a graphical format.

has been reported to be mediated by members of the MAPK family (Hocevar et al. 1999). The MAPK family incorporates the ERK pathway (Marais \& Marshall 1996) and two stress activated pathways, the JNK and p38 pathways (Kyriakis \& Avruch 1996, Woodgett et al. 1996). Consistent with our results, the JNK pathway is stimulated rapidly by TGF- $\beta$ in a human fibrosarcoma cell line, and this activity is essential for TGF- $\beta$ mediated FN induction (Hocevar et al. 1999). Similar to our results, these authors demonstrated that Smad4 is not required for TGF- $\beta$-mediated $\mathrm{FN}$ induction. Interestingly, there are several activator protein 1 (AP1) binding sites in the $F \mathcal{N}$ promoter region, which are the target of downstream signaling following TGF- $\beta$ activation (Hocevar et al. 1999). We speculate that $\mathrm{T}_{3}$ induces TGF- $\beta$ and the JNK/p38 pathway to phosphorylate AP1, allowing it to bind to the AP1 sites in the $F \mathcal{N}$ promoter and thus activate $\mathrm{FN}$ expression.
Several other factors have been demonstrated to affect the expression of FN. Recombinant human interleukin-1 administered to rats was shown to increase plasma FN levels, concomitant with increased FN in the liver (Hagiwara et al. 1990). In addition, human cytomegalovirus (HCMV)infected fibroblasts exhibited a progressive loss of cellular FN (Pande et al. 1990). These authors demonstrated that this decrease occurred at the transcriptional level and suggested that HCMVencoded and/or -induced factors may induce these alterations. Vitamin A-deficient rats had increased levels of $\mathrm{FN}$ in their serum and it was demonstrated that regulation by vitamin $\mathrm{A}$ is at the level of transcription (Kim \& Wolf 1987). Interestingly, all-trans retinoic acid (RA) induces FN expression, up to $130 \%$, at the transcriptional level in bovine lens epithelial cells (Shanker \& Sawhney 1996). Insulin-like growth factor-I (IGF-I) and insulin induce the level of $\mathrm{FN}$ in the culture media of smooth muscle cells (SMG) whereas only IGF-I upregulates $\mathrm{FN}$ in cell lysates from glomerular mesangial cells (Tamaroglio \& Lo 1994). The liver regeneration process after surgery has been demonstrated to increase $F \mathcal{N}$ mRNA threefold (Caputi et al. 1995). Ehretsmann et al. (1995) reported that treatment of the human fibrosarcoma cell line HT-1080 with dexamethasone (DEX) results in the induction of FN protein and mRNA synthesis. These authors, through the use of nuclear run-on experiments, demonstrated that the DEXdependent induction of FN occurs primarily at the post-transcriptional level. Vollmer et al. reported (1995) that $\mathrm{FN}$ is an estrogen-repressed protein in rat endometrial adenocarcinoma cells. This research indicates that different steroid hormones can affect the production of $\mathrm{FN}$ in the liver in different ways.

Our results have demonstrated that $\mathrm{T}_{3}$ plays an important role in the expression of $\mathrm{FN}$ protein at the transcriptional and post-transcriptional level. The induction of $\mathrm{FN}$ by $\mathrm{T}_{3}$ was demonstrated to be indirect as there was an absolute requirement for de novo protein synthesis. We further elucidated that $\mathrm{FN}$ activation by $\mathrm{T}_{3}$ is mediated, at least in part, by the TGF- $\beta$, JNK/p38 pathway. In addition, we established that the TGF- $\beta$ pathway, in particular Smad3 and Smad4, was not implicated in FN induction by $\mathrm{T}_{3}$. Further study is required to dissect the regulatory cascade induced by the $\mathrm{T}_{3}$ activation of fibronectin expression. 


\section{Acknowledgements}

This work was supported by grants from Chang-Gung University (CMRP 737, NMRP 092) and the National Science Council of the Republic of China (NSC 87-2316-B-182-002).

\section{References}

Balza E, Borsi L, Allemanni G \& Zardi L 1988 Transforming growth factor beta regulates the levels of different fibronectin isoforms in normal human cultured fibroblasts. FEBS Letters 228 $42-44$.

Baumgartner-Parzer SM, Wagner L, Reining G, Sexl V, Nowotny P, Muller M, Brunner M \& Waldhausl W 1997 Increase by tri-iodothyronine of endothelin-1, fibronectin and von Willebrand factor in cultured endothelial cells. Fournal of Endocrinology 154 231-239.

Bhat MK, McPhie P \& Cheng SY 1995 Interaction of thyroid hormone nuclear receptor with antibody: characterization of the thyroid hormone binding site. Biochemical and Biophysical Research Communications $210464-471$.

Borsi L, Castellani P, Risso AM, Leprini A \& Zardi L 1990 Transforming growth factor-beta regulates the splicing pattern of fibronectin messenger RNA precursor. FEBS Letters $\mathbf{2 6 1}$ 175-178.

Calloni GW, Alvarez-Silva M, Vituri C \& Trentin AG 2001 Thyroid hormone deficiency alters extracellular matrix protein expression in rat brain. Developmental Brain Research 126 121-124.

Caputi M, Melo CA \& Baralle FE 1995 Regulation of fibronectin expression in rat regenerating liver. Nucleic Acids Research $\mathbf{2 3}$ 238-243.

Chang G, Lin Y, O-Lee TW, Chou CK, Lee TS, Liu TJ, P'Eng FK, Chen TY \& Hu CP 1983 Induction of plasma protein secretion in a newly established human hepatoma cell line. Molecular and Cellular Biology 3 1133-1137.

Cheng SY 2000 Multiple mechanisms for regulation of the transcriptional activity of thyroid hormone receptors. Reviews in Endocrine and Metabolic Disorders 1 9-18.

Corica F, Allegra A, Corsonello A, Buemi M, Rubino F, Bonanzinga S, Ruello A \& Ceruso D 1998 Increased transforming growth factor-betal plasma concentration is associated with high plasma $3,3^{\prime}, 5^{\prime}$-tri-iodothyronine in elderly patients with nonthyroidal illnesses. European Fournal of Endocrinology 138 47-50.

Ehretsmann CP, Chandler LA \& Bourgeois S 1995 A nuclear post-transcriptional mechanism mediates the induction of fibronectin by glucocorticoids. Molecular and Cellular Endocrinology 110 185-194.

Flores-Morales A, Gullberg H, Fernandez L, Stahlberg N, Lee NH, Vennstrom B \& Norstedt G 2002 Patterns of liver gene expression governed by TRbeta. Molecular Endocrinology 16 1257-1268.

Hagiwara T, Suzuki H, Kono I, Kashiwagi H, Akiyama Y \& Onozaki K 1990 Regulation of fibronectin synthesis by interleukin-1 and interleukin-6 in rat hepatocytes. American fournal of Pathology 136 39-47.

Hocevar BA, Brown TL \& Howe PH 1999 TGF-beta induces fibronectin synthesis through a c-Jun N-terminal kinase-dependent, Smad4-independent pathway. EMBO Journal 18 $1345-1356$

Hynes R 1985a Molecular biology of fibronectin. Annual Review of Cell and Developmental Biology 1 67-90.

Hynes RO $1985 b$ Fibronectins: a family of complex and versatile adhesive glycoproteins derived from a single gene. The Harvey Lectures 81 133-152.
Islami D, Shoukir Y, Dupont P, Campana A \& Bischof P 2001 Is cellular fibronectin a biological marker for pre-eclampsia? European Fournal of Obstetrics, Gynecology, and Reproductive Biology 97 $40-45$.

Itoh S, Itoh F, Goumans MJ \& Ten Dijke P 2000 Signaling of transforming growth factor-beta family members through Smad proteins. European Fournal of Biochemistry $2676954-6967$.

Kim HY \& Wolf G 1987 Vitamin A deficiency alters genomic expression for fibronectin in liver and hepatocytes. Fournal of Biological Chemistry 262 365-337.

Kuang WW, Thompson DA, Hoch RV \& Weigel RJ 1998 Differential screening and suppression subtractive hybridization identified genes differentially expressed in an estrogen receptor-positive breast carcinoma cell line. Nucleic Acids Research 26 1116-1123.

Kyriakis JM \& Avruch J 1996 Protein kinase cascades activated by stress and inflammatory cytokines. Bioessays 18 567-577.

Lazar J, Desvergne B, Zimmerman EC, Zimmer DB, Magnuson MA \& Nikodem VM 1994 A role for intronic sequences on expression of thyroid hormone receptor alpha gene. Fournal of Biological Chemistry $26920352-20359$.

Lee J, Murata Y, Seo H, Menjo M, Torii S \& Matsui N 1992 The effect of thyroid hormone on fibronectin messenger ribonucleic acid levels in primary cultured rat hepatocytes. Endocrinology 130 2733-2738.

Liao JK, Zulueta JJ, Yu FS, Peng HB, Cote CG \& Hassoun PM 1995 Regulation of bovine endothelial constitutive nitric oxide synthase by oxygen. Journal of Clinical Investigation 96 2661-2666.

Lin K, Chen S, Zhu XG, Shieh H, McPhie P \& Cheng S 1997 The gene regulating activity of thyroid hormone nuclear receptors is modulated by cell-type specific factors. Biochemical and Biophysical Research Communications 238 280-284.

Lin KH, Shieh HY \& Hsu HC 2000 Negative regulation of the antimetastatic gene Nm23-H1 by thyroid hormone receptors. Endocrinology $1412540-2547$.

Lin KH, Wang WJ, Wu YH \& Cheng SY 2002 Activation of antimetastatic Nm23-H1 gene expression by estrogen and its alpha-receptor. Endocrinology 143 467-475.

Marais R \& Marshall CJ 1996 Control of the ERK MAP kinase cascade by Ras and Raf. Cancer Survey 27 101-125.

Miller LD, Park KS, Guo QM, Alkharouf NW, Malek RL, Lee NH, Liu ET \& Cheng SY 2001 Silencing of Wnt signaling and activation of multiple metabolic pathways in response to thyroid hormone-stimulated cell proliferation. Molecular and Cellular Biology $216626-6639$.

Murata Y, Seo H, Sekiguchi K, Imai T, Lee J \& Matsui N 1990 Specific induction of fibronectin gene in rat liver by thyroid hormone. Molecular Endocrinology 4 693-699.

Pande H, Terramani T, Tressel T, Churchill MA, Hawkins GG \& Zaia JA 1990 Altered expression of fibronectin gene in cells infected with human cytomegalovirus. Fournal of Virology 64 1366-1369.

Pankov R \& Yamada KM 2002 Fibronectin at a glance. Fournal of Cell Science 115 3861-3863.

Samuels HH, Stanley F \& Casanova J 1979 Depletion of L-3,5,3'-triiodothyronine and L-thyroxine in euthyroid calf serum for use in cell culture studies of the action of thyroid hormone. Endocrinology 105 80-85.

Sekiguchi K, Klos AM, Kurachi K, Yoshitake S \& Hakomori S 1986 Human liver fibronectin complementary DNAs: identification of two different messenger RNAs possibly encoding the alpha and beta subunits of plasma fibronectin. Biochemistry 25 4936-4941.

Shanker G \& Sawhney R 1996 Retinoic acid: identification of specific receptors through which it may mediate transcriptional regulation of fibronectin gene in bovine lens epithelial cells. Cell Biology International 20 613-619. 
Shirakami A, Hirai Y, Takeichi T, Nishino H, Inomoto T, Watanabe S, Shigekiyo T, Kawauchi S, Saito H \& Saito S 1986 Changes in plasma fibronectin levels in thyroid diseases. Hormone and Metabolism Research 18 345-348.

Srebrow A, Blaustein M \& Kornblihtt AR 2002 Regulation of fibronectin alternative splicing by a basement membrane-like extracellular matrix. FEBS Letters 514 285-289.

Suzuki M, Oda E, Nakajima T, Sekiya S \& Oda K 1998 Induction of Spl in differentiating human embryonal carcinoma cells triggers transcription of the fibronectin gene. Molecular and Cellular Biology 18 3010-3020.

Tamaroglio TA \& Lo CS 1994 Regulation of fibronectin by insulin-like growth factor-I in cultured rat thoracic aortic smooth muscle cells and glomerular mesangial cells. Experimental Cell Research 215 338-346.

Vollmer G, Hopert AC, Ellerbrake N, Wunsche W \& Knuppen R 1995 Fibronectin is an estrogen-repressed protein in RUCA-I rat endometrial adenocarcinoma cells. Fournal of Steroid Biochemistry and Molecular Biology 54 131-139.
Watzke H, Schwarz HP \& Weissel M 1987 Fibronectin during thyroid hormone replacement therapy. Thrombosis Research $\mathbf{4 6}$ 347-353.

Wood WM, Dowding JM, Bright TM, McDermott MT, Haugen BR, Gordon DF \& Ridgway EC 1996 Thyroid hormone receptor beta2 promoter activity in pituitary cells is regulated by Pit- 1 . Fournal of Biological Chemistry 271 24213-24220.

Woodgett JR, Kyriakis JM, Avruch J, Zon LI, Zanke B \& Templeton DJ 1996 Reconstitution of novel signalling cascades responding to cellular stresses. Philosophical Transactions of the Royal Society of London. Series B, Biological Sciences 351 135-141; discussion 142 .

\section{Received 2 May 2004}

Accepted 29 June 2004

Made available online as an Accepted Preprint 8 July 2004 